\section{DIGITAL COMMONS \\ @ UNIVERSITY OF SOUTH FLORIDA}

\section{ABO: Interactive Journal for Women in the Arts, 1640-1830}

Volume 8

Issue 1 Spring 2018

Article 4

2018

\title{
Review of The Ladies of Llangollen: Desire, Indeterminacy, and the Legacies of Criticism
}

\author{
Dawn M. Goode \\ James Madison University, goodedm@jmu.edu
}

Follow this and additional works at: https://digitalcommons.usf.edu/abo

Part of the Feminist, Gender, and Sexuality Studies Commons, and the Literature in English, British Isles Commons

\section{Recommended Citation}

Goode, Dawn M. (2018) "Review of The Ladies of Llangollen: Desire, Indeterminacy, and the Legacies of Criticism," ABO: Interactive Journal for Women in the Arts, 1640-1830: Vol.8: Iss.1, Article 4. https://doi.org/10.5038/2157-7129.8.1.1192

Available at: https://digitalcommons.usf.edu/abo/vol8/iss1/4

This Reviews is brought to you for free and open access by Digital Commons @ University of South Florida. It has been accepted for inclusion in ABO: Interactive Journal for Women in the Arts, 1640-1830 by an authorized administrator of Digital Commons @ University of South Florida. For more information, please contact digitalcommons@usf.edu. 
Review of The Ladies of Llangollen: Desire, Indeterminacy, and the Legacies of Criticism

\begin{abstract}
Review of The Ladies of Llangollen: Desire, Indeterminacy, and the Legacies of Criticism. Bucknell UP, 2017. xxxvi + 331pp. Index. ISBN: 978-1-6114-8761-9.
\end{abstract}

Keywords

Romantic friendship, female same-sex desire, queer historiography, Romanticism, bluestocking

Creative Commons License

(c) (1) (5)

This work is licensed under a Creative Commons Attribution-Noncommercial 4.0 License 
Brideoake, Fiona. The Ladies of Llangollen: Desire, Indeterminacy, and the Legacies of Criticism. Bucknell UP, 2017. xxxvi + 331pp. Index. ISBN: 978-1-6114-8761-9.

Reviewed by Dawn M. Goode

James Madison University

Although the subject of few full-length studies, the elopement and subsequent 51-year relationship between Eleanor Butler and Sarah Ponsonby has been ubiquitous in its deployment within popular culture and critical scholarship, playing, according to Fiona Brideoake, "a central role in the conceptualization of female same-sex desire" for over 200 years (xxvi). In The Ladies of Llangollen, however, it is the "plasticity of [the Ladies'] cultural presence" (xvii) across those years that takes center stage. Through a publicly performed "self-fashioning," Butler and Ponsonby ensured the "essential inscrutability of their intimacy" (xxvi) and, as a result, their resistance to having an identity "reducible to their same-sex attachment" (xviii). Unable to be restricted to "a single, stable signification," Butler and Ponsonby act as queer ciphers, stand-ins for a wide range of desires and identities. Using a queer historicist approach - one influenced by the work of Dinshaw, Freccerro, and Nealon for example - Brideoake enlists textual sources, material culture, and sociable practices to reveal Butler and Ponsonby's self-fashioning maneuvers as well as the various, and often conflicting, cultural meanings that have been projected onto their relationship from the Eighteenth century until the present day. The queerness of Butler and Ponsonby is not limited however to the indecipherability of their relationship or the variability of the identities projected onto them, but also includes their ability to destabilize critical understandings of bluestocking feminism, Romanticism, and sexuality studies.

The first two chapters of The Ladies of Llangollen examine contemporary and critical representations of Butler and Ponsonby that attempt to categorize the nature of their intimacy. Chapter 1 offers a quick history of the Butler and Ponsonby families, the women's early interactions, and the ambivalent response of friends and families to their relationship. Chapter 2 traces the scholarly appropriation of Butler and Ponsonby's relationship to authorize a multitude of competing subject positions and ideologies relevant to the critical history of female same-sex sexuality. The emphasis in Chapters 3 and 4 shifts to examining the textual and material means through which Butler and Ponsonby crafted their joint identity to detract any suspicion regarding the nature of their intimacy. Chapters 5 and 6 locates Butler and Ponsonby's place in contemporary and current understandings of bluestocking culture and Romanticism while Chapter 7 looks at Butler and Ponsonby in relation to early twentieth-century constructions of homosexuality and the transtemporality of queerness.

In addition to chronicling the familial history of each woman, Chapter 1 presents some of the earliest depictions of Butler and Ponsonby's relationship and their subsequent elopement. These depictions reveal the period's ambivalent readings of female friendship as both chaste and suspect. Brideoake also corrects the standard narrative of Butler and Ponsonby as being permanently estranged from their families. As part of this corrective, Brideoake details how Ponsonby's familial connections gained the women entry into the social network of the local Welsh gentry, a move that helped distance them from their suspect identities as spinster Irish exiles. 
With Chapter 2, Brideoake examines the critical deployment of Butler and Ponsonby's biographical narrative to excavate the history of female same-sex desire. Evidencing a comprehensive familiarity with this scholarship, Brideoake takes up the competing gendered frameworks within which Butler and Ponsonby have been situated from the time of their elopement to the present day. Within feminist scholarship, Butler and Ponsonby's relationship has been lauded as the model of chaste romantic friendship, used to highlight the potential homoeroticism in such friendships, and decried as a self-serving closeting of lesbian desire. Brideoake argues that their reification under the romantic friendship model simultaneously occurred alongside a tradition in which they were identified as a gender-differentiated, sexually transgressive couple. For Brideoake, the "parallel histories of these two mutually exclusive representational traditions" make evident Butler and Ponsonby's queer indecipherability while also revealing "the essential instability of the genealogies and identities they are claimed to secure" (20).

In Chapter 3, Brideoake attends to the geographical and material means through which Butler and Ponsonby allayed suspicions about the nature of their relationship. Establishing that earlier romantic travel narratives ignored or denigrated the uninspiring village of Llangollen while celebrating its more picturesque valley, Brideoake reads Butler and Ponsonby's decision to live outside the village center as a disavowal of the village's poverty and a claim on the aesthetic sensibilities of the vale's gentry families. This claim was strengthened through their textual selffashioning - the beginnings of which, Brideoake argues, manifest in Ponsonby's 1778 travel journal, An Account of a Journey in Wales. Brideoake reads both the journal's material construction and its contents as a performance of genteel sensibility, a performance mirrored in Butler's day journals which were heavy on conversational points and anecdotes, but short on meaningful interiority. For Brideoake, Butler and Ponsonby's "textual fashioning of a notably unrevealing privacy" (81) offers an early example of their queer performativity. In the final section of this chapter, Brideoake traces the genealogy of Butler and Ponsonby's collective identity as "the Ladies of Llangollen," one forged by their "employment of place as a marker of identity" (84). Here, Brideoake describes how Butler and Ponsonby's spatial and textual identification with Llangollen Vale enabled their entry into local gentry social circles which in turn allowed them to successfully reconstitute themselves "from exiled Irish spinsters to indigenous elements of the Welsh cultural and geographical landscape" (72).

Delineating Butler and Ponsonby's efforts to fashion themselves as "sexually virtuous Welsh landowners" (92) continues in Chapter 4, one of Brideoake's strongest chapters. Focusing upon the cultural production of Butler and Ponsonby's home, Plas newydd, Brideoake argues that their architectural renovations, farming practices and various private collections "allowed Butler and Ponsonby to identify with the social and geographical fixity of the local Welsh gentry" (xxx), an identification necessary to mask their social marginality as exiled Irish spinsters. Brideoake first locates Butler and Ponsonby's renovation of Plas newydd within the cottage ornée tradition which transformed the modest home of the rural working class into an "idealized site of retirement and conjugal love" indicative of a refined sensibility (102). In transforming Plas newyyd into a cottage ornée, Butler and Ponsonby called forth the similarly featured homes of the local Anglo-Welsh gentry - a class marked by social and geographic stability, and associated with social and sexual virtue (100). Gothic improvements - such as the library's stained-glass window - the installment of the oak paneling found in local gentry homes, and their private 
library helped reify Butler and Ponsonby's identity as established Welsh landowners (rather than the tenants they were) and in doing so distanced them from "the social and sexual mobility of rumored metropolitan sapphists" (xxx).

The examination of Butler and Ponsonby's use and production of bluestocking culture to further legitimize their relationship anchors Chapter 5. Brideoake uses a third of this chapter to identify key figures and practices of the bluestocking networks of the 1760s and 1770s - in particular, the metropolitan salons of Vesey and Montagu and the provincial communities like those linked to Scott and Fielding. Challenging bluestocking criticism that has situated metropolitan literary sociability in contrast to the provincial model of scholarly retirement, Brideoake argues that sociability and scholarship interpenetrated each bluestocking geography. With this reformulation of bluestocking culture, Brideoake reads Butler and Ponsonby as performing a hybrid bluestocking practice that incorporated the retirement advocated by Scott and the sociability associated with Montague. For Brideoake, the identification of Butler and Ponsonby as cultural producers of bluestocking culture raises the critical need to more broadly define what constituted bluestocking culture. While certainly there is validity in challenging criticism's bifurcated understanding of bluestocking culture, Brideoake seems somewhat to lose Butler and Ponsonby along the way as this chapter would have benefited from a more sustained exploration of Butler and Ponsonby's textual, material, and relational efforts to fashion themselves as bluestockings.

Staying with the idea of Butler and Ponsonby as producers of culture, Chapter 6 makes a strong claim for the recognition of their centrality to canonical Romanticism. Brideoake examines the valorization of their enduring domesticity in the poetry of Seward and Wordsworth and in the life writings of Byron and Lister. The dueling sexual significations assigned to that domesticity underscore the plasticity of Butler and Ponsonby's public image. Their self-fashioned domesticity also stands as a key example "of the Romantic nexus between domesticity and subjectivity, revealing the material means through which the Romantic subject was publicly constituted" (188). In an extended reading of Seward's "The Vale of Llangollen," Brideoake argues that Seward distances the women's relationship from sexualized associations by aligning their domesticity to civility, sensibility, and the feminization of culture. In doing so, Seward advocates for a form of affective female same-sex cohabitation that she wished for herself. In "To the Lady E.B. and the Hon. Miss P," Wordsworth uses Plas newydd as a metonymic stand-in for Butler and Ponsonby, and makes legible another form of Romantic identity construction. The sonnet displaces the women's bodies with their shared home, "anticipat[ing] the more famous home- and self-making" of Wordsworth at Dove Cottage, and revealing the means through which the "deep Romantic self was publicly constituted, as domestic spaces came to stand as symbolic instantiations of the 'authentic' Romantic self"' (210).

Brideoake then enlists Byron and Lister to highlight Butler and Ponsonby's "function as mobile signifiers of enduring queer desire" (213). While Byron emphasizes the enduring nature of Butler and Ponsonby's sexualized relationship, Lister imbricates desire with their enduring domesticity. The simultaneity of these configurations illustrates the "conceptual mobility" conveyed upon Butler and Ponsonby by "the indeterminacy of their sexual affect" (218). Brideoake notes that Byron's self-consciously staged identity resulted in his reduction to "a commodity identified with his textual creations," one "subject to an array of competing representations" and appropriations, much like Butler and Ponsonby (214). In another example of Romantic identity 
production, Lister coopts Byronic masculinity and the Ladies' domesticity to craft a same-sex relational identity inclusive of both desire and enduring domesticity, effectively queering Romanticism itself. For Brideoake, reading Butler and Ponsonby across the Romantic century reveals them as producers of canonical Romanticism, and encourages a reconceptualization of its supposed articulation of an authentic, solitary, male self (xxvii).

With a well-conceived Chapter 7, Brideoake explores textual figurations of Butler and Ponsonby between 1928 - 1937, a period she identifies as being preoccupied with making female same-sex desire visible. While Radclyffe Hall's 1928 The Well of Loneliness martyrizes the female sexual invert in a "narrative of queer suffering," Virginia Woolf's 1928 Orlando and Mary Louisa Gordon's 1936 Chase of the Wild Goose reconfigure the narrative of sexology "to undergird a more expansive form of sapphic modernity" (244). Writing about the modern sapphist within the historical novel genre, both Woolf and Gordon invoke Butler and Ponsonby "as an enabling myth of contemporary queer relationality" (245). Gordon's fictionalized biography of Butler and Ponsonby receives most of Brideoake's attention in this chapter. While Wild Goose aligns with sexology's gender-transitivity model of female inversion, it rejects the heteronormative logic of that model. Through rewriting the history of Butler and Ponsonby, Gordon makes distinctions between sex, gender, and sexuality, detaches masculinity from maleness, and imbues the invert's feminine partner with sexual agency. Reading Wild Goose through Nealon's concept of affect genealogies and Derrida's hauntology, Brideoake reads Gordon as articulating a "model of queer reproduction in which Butler and Ponsonby gives birth to the future Gordon embodies, this metaphorical kinship rendered literal as they reappear in the modern area" (261). Depicted as having a proto-feminist and refined sensibility that set them apart from their own time and place, Butler and Ponsonby are both of the past and of Gordon's present, reflecting Dinshaw's temporal asynchronicity. As "queer time travelers" (264), Butler and Ponsonby "anticipate and enable the sexual and gendered freedoms both earned and asserted in the first decades of the twentieth century" (239), effectively "queering the linear trajectory of traditional history" (267). Read in these terms, Butler and Ponsonby anticipate Brideoake's own queer project, one that looks to the past at the same time that it illuminates the transformational and transtemporal potential of new queer historicism. 